\title{
Membangun Masyarakat Tangguh Bencana Melalui Sosialisasi dan Edukasi Modal Sosial Di Kabupaten Klaten
}

\author{
1, 2* Yunus Aris Wibowo, ${ }^{3}$ Lintang Ronggowulan, ${ }^{1}$ Ayu Fatonah, ${ }^{1}$ Rose Ana Anggun Fajariyah \\ ${ }^{1}$ Pendidikan Geografi, Fakultas Keguruan dan Ilmu Pendidikan, Universitas Muhammadiyah Surakarta \\ ${ }^{2}$ Pusat Studi Mitigasi Bencana, Universitas Muhammadiyah Surakarta \\ ${ }^{3}$ Pendidikan Geografi, Fakultas Keguruan dan Ilmu Pendidikan, Universitas Sebelas Maret \\ *Penulis korespondensi, email: yaw222@ums.ac.id
}

(Received: 11 November 2020/Accepted: 12 Januari 2021/Published: 28 Januari 2021)

\begin{abstract}
Abstrak
Gempabumi merupakan salah satu bencana alam yang sangat merusak dan dapat mengakibatkan korban luka, meninggal dunia, kerusakan sarana prasarana dan terganggunya jaringan sosial. Kabupaten Klaten merupakan salah satu wilayah paling rawan dan rentan terhadap gempabumi. Oleh karena itu, dibutuhkan manajemen bencana yang baik secara struktur maupun implementasinya. Salah satu variabel penting dalam manajemen bencana adalah modal sosial (social capital) masyarakat karena modal sosial (social capital) merupakan salah satu unsur dalam strategi penghidupan (livelihood) masyarakat. Pengetahuan masyarakat Kabupaten Klaten akan pentingnya modal sosial (social capital) perlu ditingkatkan, salah satunya melalui sosialisasi terhadap organisasi kemasyarakatan Nasyiatul Aisyiyah Klaten Selatan. Sosialisasi dilaksanakan selama satu hari dengan melibatkan 64 orang peserta anggota Nasyiatul Aisyiyah Klaten Selatan. Peningkatan pengetahuan dan kesadaran masyarakat terhadap pentingnya modal sosial (social capital) dalam menghadapi bencana gempabumi diharapkan dapat meningkatkan kapasitas (capacity) masyarakat dan menurunkan tingkat kerentanan (vulnerability), sehingga risiko (risk) bencana gempabumi di Kabupaten Klaten juga dapat dikurangi.
\end{abstract}

Kata Kunci : Bencana, gempabumi, modal sosial, kapasitas, kerentanan

\begin{abstract}
Earthquake is one of the most devastating disaster which can trigger injuries, death tolls, infrastructures damage and social network disruption. Klaten Regency is one of the most susceptible and vulnerable area by earthquake. Therefore, it needs a proper disaster management planning and its implementation. Social capital of society is an essential variable of disaster management because it is one of crucial factors of society livelihood. The knowledge and awareness of Klaten Regency society toward social capital should be improved by giving a counselling for social organization (the Nasyiatul Aisyiyah of South Klaten Sub District). The counselling was conducted in one day seminar involving 64 member of the Nasyiatul Aisyiyah of South Klaten Sub District, Muhammadiyah Youth Force Command (KOKAM), and Muhammadiyah Management Center. Overall, by improving knowledge and awareness of Klaten Regency society toward social capital, the society capacity can be improved; not to mention, the vulnerability can be reduced so that earthquake disaster risk in Klaten Regency can be reduced as well.
\end{abstract}

Keywords: disaster, earthquake, social capital, capacity, vulnerability 


\section{Pendahuluan}

Gempabumi merupakan salah satu bahaya (hazard) yang berpotensi mengakibatkan korban jiwa dan kerugian yang sangat besar. Gempabumi adalah getaran bumi yang dapat terjadi karena peristiwa letusan gunungapi, benturan meteorit, tanah longsor, ledakan bom, dan banyak lagi penyebab lainnya; namun umumnya mereka disebabkan oleh gerakan mendadak Kerak Bumi di sepanjang bidang patahan (Abbott, 2017). Indonesia merupakan salah satu negara yang paling sering diguncang gempabumi (Muh Aris Marfai, Cahyadi, Fatchurohman, Rosaji, \& Wibowo, 2017). Hal itu karena kondisi tektonik Indonesia yang terletak pada zona pertemuan lempeng besar dunia (Lempeng Eurasia, Lempeng Pasifik, dan Lempeng Indo-Australia) dan beberapa lempeng kecil (microblocks) (Bird, 2003; Husein, 2016; M.A. Marfai, Cahyadi, Fatchurohman, Rosaji, \& Wibowo, 2019). Kondisi tektonik dan data kegempaan (seismitas) di Indonesia disajikan pada Gambar 1 dan Gambar 2.

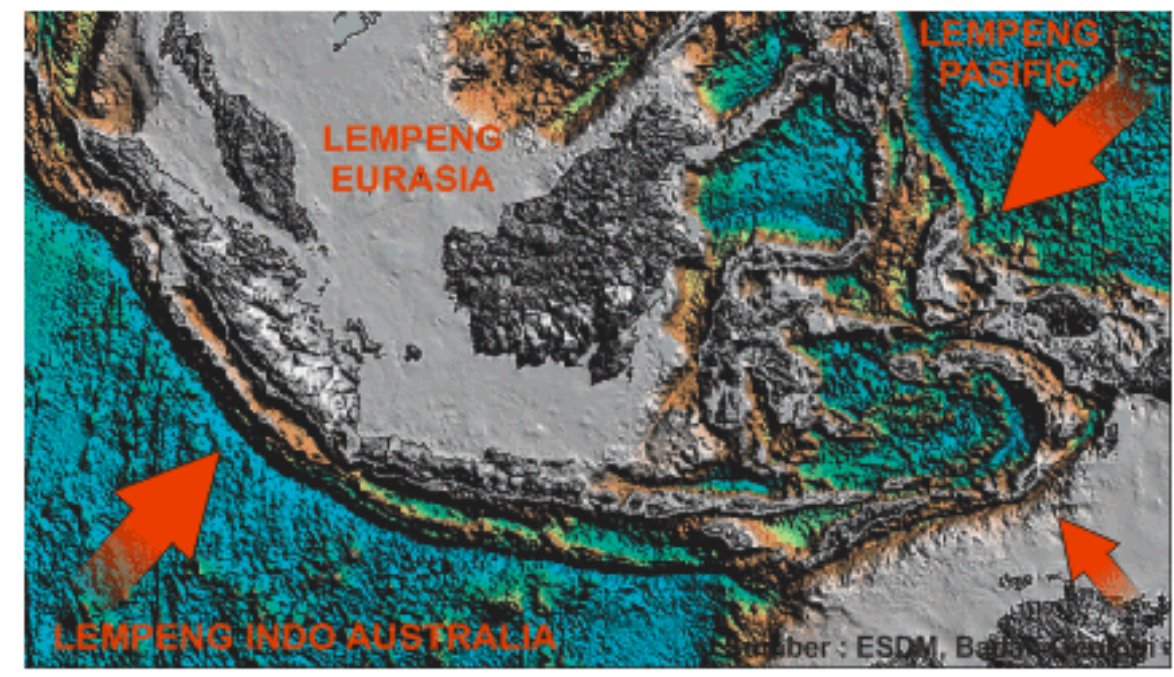

Gambar 1. Kondisi Tektonik Indonesia

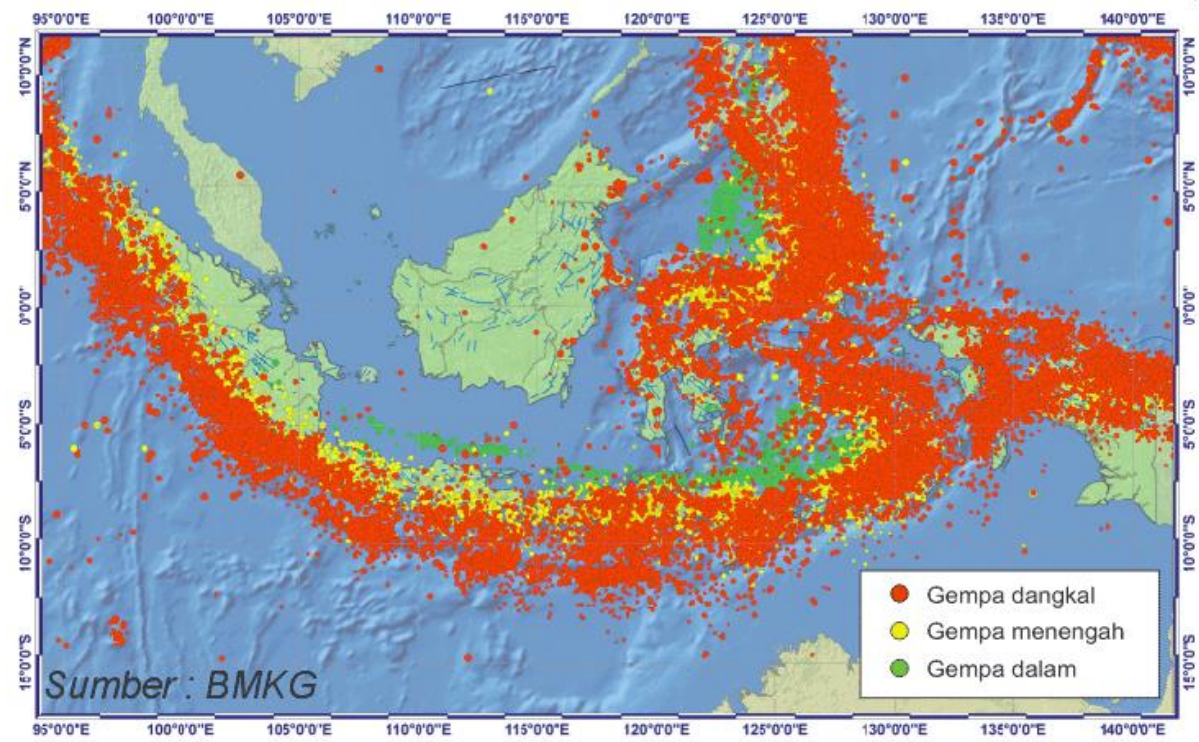

Gambar 2. Data Kegempaan (Seismisitas) di Indonesia Periode 1973 - 2010

(Sumber: BMKG, 2018 diakses 5 Oktober 2018 Pukul 19.30 WIB)

Gambar 2 menunjukkan intesitas gempabumi di Indonesia yang sangat tinggi. Kejadiankejadian tersebut bervariasi dilihat dari tingkat kedalaman maupun magnitudnya. Beberapa kejadian gempabumi tersebut telah mengakibatkan jatuhnya banyak korban jiwa di Indonesia. 
Beberapa kejadian gempabumi tektonik di Indonesia dengan jumlah korban meninggal lebih dari 1000 jiwa disajikan pada Tabel 1.

Tabel 1. Kejadian Gempabumi di Indonesia dengan Korban Jiwa Lebih Dari 1000 Jiwa

\begin{tabular}{clccr}
\hline No. & \multicolumn{1}{c}{ Wilayah } & Waktu Kejadian & Magnitude & Jumlah Korban (Jiwa) \\
\hline 1 & Aceh & 26 Desember 2004 & 9.3 & 168000 \\
2 & Papua & 26 Juni 1976 & 7.1 & 9000 \\
3 & Yogyakarta & 27 Mei 2006 & 5.9 & 6234 \\
4 & Ambon & 20 September 1899 & 7.8 & 3280 \\
5 & Sumbawa & 19 Agustus 1977 & 8.0 & 2200 \\
6 & Flores & 12 Desember 1992 & 7.5 & 2100 \\
7 & Padang & 30 September 2009 & 7.6 & 1115 \\
\hline
\end{tabular}

Sumber: (Husein, 2016)

Gempabumi yang melanda Yogyakarta Tahun 2006 menyebabkan 6234 jiwa meninggal merupakan kejadian gempabumi dengan korban jiwa terbanyak ketiga di Indonesia. Kejadian tersebut tidak hanya berdampak terdampak wilayah di Daerah Istimewa Yogyakarta, tetapi juga berdampak terhadap wilayah administrasi sekitarnya. Salah satu wilayah yang terdampak paling parah adalah Kabupaten Klaten, Provinsi Jawa Tengah. Data jumlah korban luka dan meninggal dunia akibat gempabumi 2006 di Kabupaten Klaten disajikan pada Tabel 2.

Tabel 2. Jumlah korban luka dan meninggal dunia akibat gempabumi 2006 di Kabupaten Klaten

\begin{tabular}{|c|c|c|c|}
\hline No. & Wilayah & Korban Meninggal & Korban Luka \\
\hline 1 & Bantul & 4121 & 12026 \\
\hline 2 & Sleman & 240 & 3792 \\
\hline 3 & Kota Yogyakarta & 195 & 318 \\
\hline 4 & Kulonprogo & 22 & 2179 \\
\hline 5 & Gunung Kidul & 81 & 1086 \\
\hline 6 & Klaten & 1041 & 18127 \\
\hline 7 & Magelang & 10 & 24 \\
\hline 8 & Boyolali & 4 & 300 \\
\hline 9 & Sukoharjo & 1 & 67 \\
\hline 10 & Wonogiri & 0 & 4 \\
\hline 11 & Purworejo & 1 & 4 \\
\hline & Total & 5716 & 37927 \\
\hline
\end{tabular}

Sumber: (Elnashai, Kim, Yun, \& Sidarta, 2006)

Kabupaten Klaten merupakan wilayah di Provinsi Jawa Tengah dengan tingkat kerusakan paling parah. Hal itu disebabkan karena letak Kabupaten Klaten yang berbatasan langsung dengan Daerah Istimewa Yogyakarta, selain itu juga karena secara geologis sebagian wilayah Kabupaten Klaten dilalui oleh Sesar Dengkeng yang memperparah bencana yang terjadi. Selain korban jiwa dan luka-luka, bencana gempabumi Tahun 2006 mengakibatkan kerugian, yaitu rusaknya atau robohnya bangunan fisik 157000 unit permukiman, prasarana pendidikan, kesehatan, pemerintahan dan ekonomi yang merupakan bagian dari aset penghidupan masyarakat (livelihood) (Elnashai et al., 2006). Data kerugian prasarana kesehatan disajikan Tabel 2. dan kerugian prasarana pendidikan disajikan pada Tabel 3., sedangkan bentuk kerusakan bangunan akibat bencana gempabumi Yogyakarta Tahun 2006 disajikan pada Gambar 3. 
Tabel 3. Kerugian prasarana kesehatan akibat bencana gempabumi Yogyakarta Tahun 2006

\begin{tabular}{clrrr}
\hline Provinsi & Kabupaten & \multicolumn{1}{c}{ Rusak } & \multicolumn{1}{c}{ Hancur } & \multicolumn{1}{c}{ Total } \\
(miliar rupiah) & (miliar rupiah) & (miliar rupiah) \\
\hline & Sleman & 198.237 & 1.487 & 199.724 \\
& Bantul & 418.38 & 4.449 & 422.829 \\
Yogyakarta & 169.115 & 1.147 & 170.262 \\
& Gunung Kidul & 604.4 & 7.42 & 611.82 \\
& Yogyakarta & 17.927 & 0.133 & 18.06 \\
\hline Kulonprogo & $\mathbf{1 4 0 8 . 0 5 9}$ & $\mathbf{1 4 . 6 3 6}$ & $\mathbf{1 4 2 2 . 6 9 5}$ \\
\hline \multirow{2}{*}{ Jawa Tengah } & Total & 15.291 & 0.403 & 15.694 \\
& Klaten & 86.678 & 5.601 & 92.279 \\
\hline & Kabupaten- & $\mathbf{1 0 1 . 9 6 9}$ & $\mathbf{6 . 0 0 4}$ & $\mathbf{1 0 7 . 9 7 3}$ \\
\hline & & &
\end{tabular}

Sumber: (Elnashai et al., 2006)

Tabel 4. Kerugian prasarana pendidikan akibat bencana gempabumi Yogyakarta Tahun 2006

\begin{tabular}{|c|c|c|c|c|c|c|c|c|}
\hline \multirow[b]{2}{*}{ No. } & \multirow[b]{2}{*}{ Provinsi } & \multicolumn{3}{|c|}{ Rusak } & \multirow[b]{2}{*}{ Hancur } & \multirow[b]{2}{*}{ Total } & \multicolumn{2}{|c|}{ Kepemilikan } \\
\hline & & Bangunan & $\begin{array}{l}\text { Perlengkapan } \\
\text { Lain }\end{array}$ & $\begin{array}{l}\text { Sub- } \\
\text { Total }\end{array}$ & & & Negeri & Pribadi \\
\hline 1 & Jawa Tengah & 317 & 3 & 320 & 12 & 332 & 244 & 88 \\
\hline 2 & Yogyakarta & 1,304 & 59 & 1363 & 44 & 1407 & 910 & 497 \\
\hline & Total & 1,621 & 62 & 1,683 & 56 & 1,739 & 1,154 & 585 \\
\hline
\end{tabular}

Sumber: (Elnashai et al., 2006)
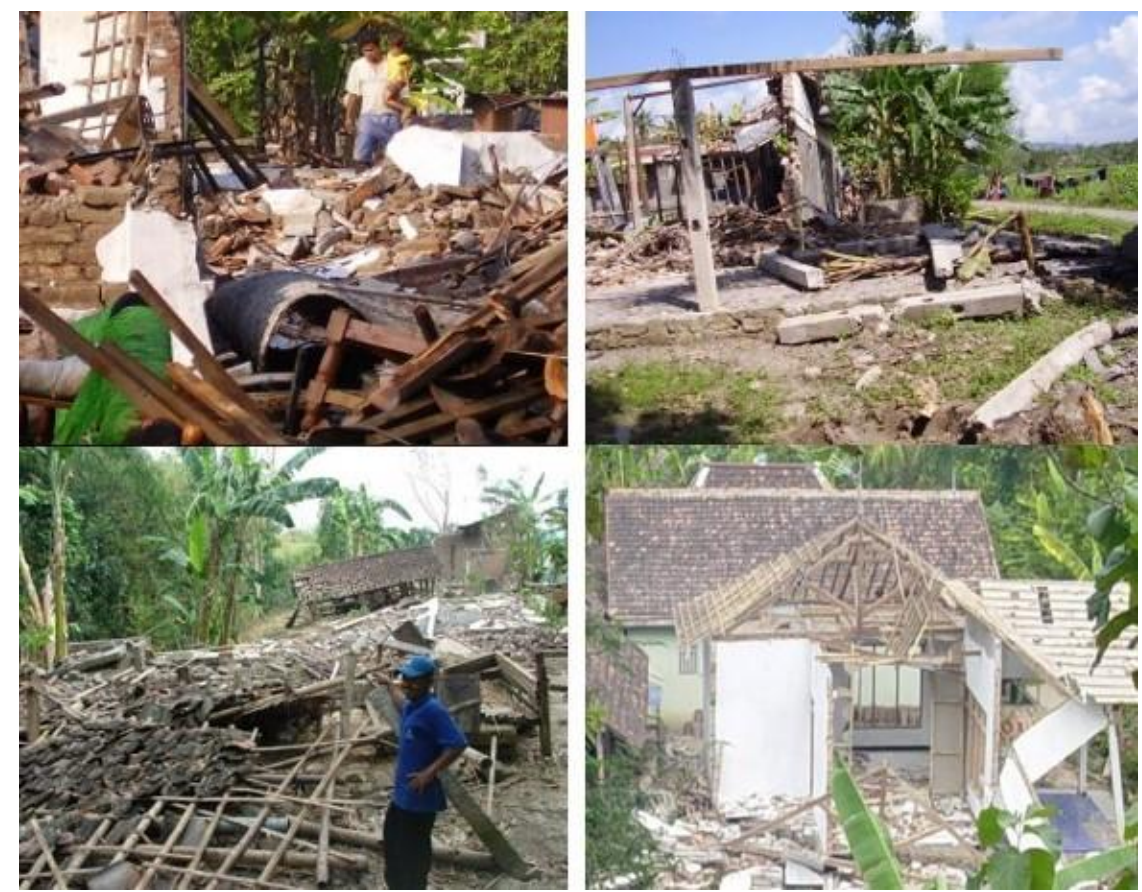

Gambar 3. Bentuk kerusakan bangunan di Yogyakarta dan Klaten akibat bencana gempabumi Yogyakarta Tahun 2006

Sumber: (Elnashai et al., 2006; Posko Kemanusiaan Dengkeng Wedi Klaten, 2006 diakses 30

Oktober 2018 Pukul 19.30 WIB)

Kerugian-kerugian yang dijelaskan di atas juga menekankan pada kerugian aset penghidupan masyarakat (livelihood) khususnya di masyarakat terdampak gempabumi. Kerugian aset 
penghidupan masyarakat (livelihood) secara detil meliputi modal manusia (human capital), modal alam (natural capital), modal fisik (physical capital), modal keuangan (financial capital) dan modal sosial (social capital) (DFID, 1999; Ellis, 1999). Kelima aspek penghidupan tersebut sangat penting dalam ketahanan dan daya lenting (resillience) masyarakat terhadap bencana. Masing-masing aspek sangat penting karena memiliki peran dan karakteristik berbeda-beda, aspek yang sangat penting tetapi masih belum banyak dikaji adalah modal sosial (social capital).

Modal sosial (social capital) merupakan ciri-ciri organisasi sosial, seperti jaringan, norma dan kepercayaan sosial yang memfasilitasi koordinasi dan kerja sama yang saling menguntungkan (Putnam, 1993). Modal sosial dibangun dari budaya dan kebiasaan masyarakat maupun dari bentuk-bentuk kerikatan lainnya sehingga membentuk jaringan sosial yang kuat (Hsueh, 2019; Karunarathne \& Lee, 2019; Monteil, Simmons, \& Hicks, 2020). Keberadaan jaringan sosial atau komunitas yang kuat dalam suatu masyarakat dapat meningkatkan ketahanan dan daya lenting (resillience) masyarakat dalam menghadapi bencana (Story et al., 2020).

Bentuk-bentuk modal sosial yang sering kita temukan dalam masyarakat khususnya masyarakat jawa di antaranya arisan, pertemuan rukun tetangga, pertemuan ibu-ibu PKK, karang taruna, organisasi keagamaan, organisasi pendidikan maupun organisasi kemasyarakatan lainnya. Jaringan tersebut terbentuk karena adanya partisipasi dalam suatu jaringan (Participation in A Network), timbal balik sosial (Reciprocity), rasa percaya (Trust), norma Sosial (Social Norms), nilai-nilai (Value) dan tindakan proaktif (Proactive action) (Hasbullah, 2006; Hsueh, 2019; Monteil et al., 2020).

Ikatan yang terbentuk dalam suatu jaringan sosial sebenarnya sangat kuat dan terstruktur baik disadari maupun tidak disadari, akan tetapi pemahaman dan pengetahuan masyarakat tentang pentingnya jaringan sosial yang merupakan modal sosial (social capital) yang sangat penting dalam menghadapi bencana masih sangat rendah. Masyarakat Kabupaten Klaten merupakan masyarakat khas Suku Jawa yang masih memegang teguh dan melestarikan budaya sosial dengan sangat baik hingga saat ini. Akan tetapi tingkat pengetahuan dan kesadaran masyarakat terhadap budaya sosial sebagai modal sosial yang mereka pegang teguh khususnya dalam menghadapi bencana gempabumi masih belum terbangun. Oleh karena itu, peningkatan pemahaman dan pengetahuan masyarakat tentang modal sosial (social capital) di wilayah rawan bencana alam seperti Kabupaten Klaten sangat perlu dilakukan. Kegiatan ini fokus pada edukasi sebagai upaya peningkatan pemahaman dan pengetahuan masyarakat tentang modal sosial (social capital) tersebut. Meningkatnya pemahaman dan pengetahuan masyarakat tentang modal sosial (social capital) khususnya di Kabupaten Klaten diharapkan dapat membangun masyarakat tangguh bencana, sehingga tingkat risiko bencana dapat dikurangi.

\section{Metode}

Pelaksanaan pengabdian masyarakat "Membangun Masyarakat Tangguh Bencana Melalui Sosialisasi dan Edukasi Modal Sosial di Kabupaten Klaten" didesain dalam tiga tahap kegiatan, yaitu tahap pra pelaksanaan, tahap pelaksanaan dan tahap pasca pelaksanaan (Gambar 4). Ketiga tahap kegiatan tersebut diuraikan lebih rinci sebagai berikut.

\subsection{Tahap Pra Pelaksanaan}

Tahap pelaksanaan dimulai dengan studi literatur untuk mengetahui daerah-daerah yang berada dalam kawasan rawan bencana dan mengetahui kekurangan-kekurangan yang harus ditingkatkan dalam manajemen bencana. Tahap selanjutnya adalah menentukan dan menghubungi mitra kegiatan untuk menyusun kegiatan yang tepat serta sesuai sasaran.

\subsection{Tahap Pelaksanaan}

Tahap pelaksanaan merupakan tahap kolaborasi antara Program Studi Pendidikan Geografi, Universitas Muhammadiyah Surakarta dan Pengurus Cabang Nasyiatul Aisyiyah Klaten Selatan. Bentuk kegiatan adalah sosialisasi dan edukasi yang dilakukan dengan pemaparan materi dengan tema "Membangun Masyarakat Tangguh Bencana Melalui Modal Sosial di Kabupaten Klaten" dilanjutkan dengan diskusi dan tanya jawab dengan peserta kegiatan. 


\subsection{Tahap Pasca Pelaksanaan}

Tahap pasca pelaksanaan sosialisasi ini adalah tahap pelaporan dan pubilkasi hasil kegiatan serta dilanjutkan dengan bentuk kerja sama antara Program Studi Pendidikan Geografi, Universitas Muhammadiyah Surakarta dan Pengurus Cabang Nasyiatul Aisyiyah Klaten Selatan dalam pelaksanaan kegiatan-kegiatan manajemen bencana di Kabupaten Klaten.

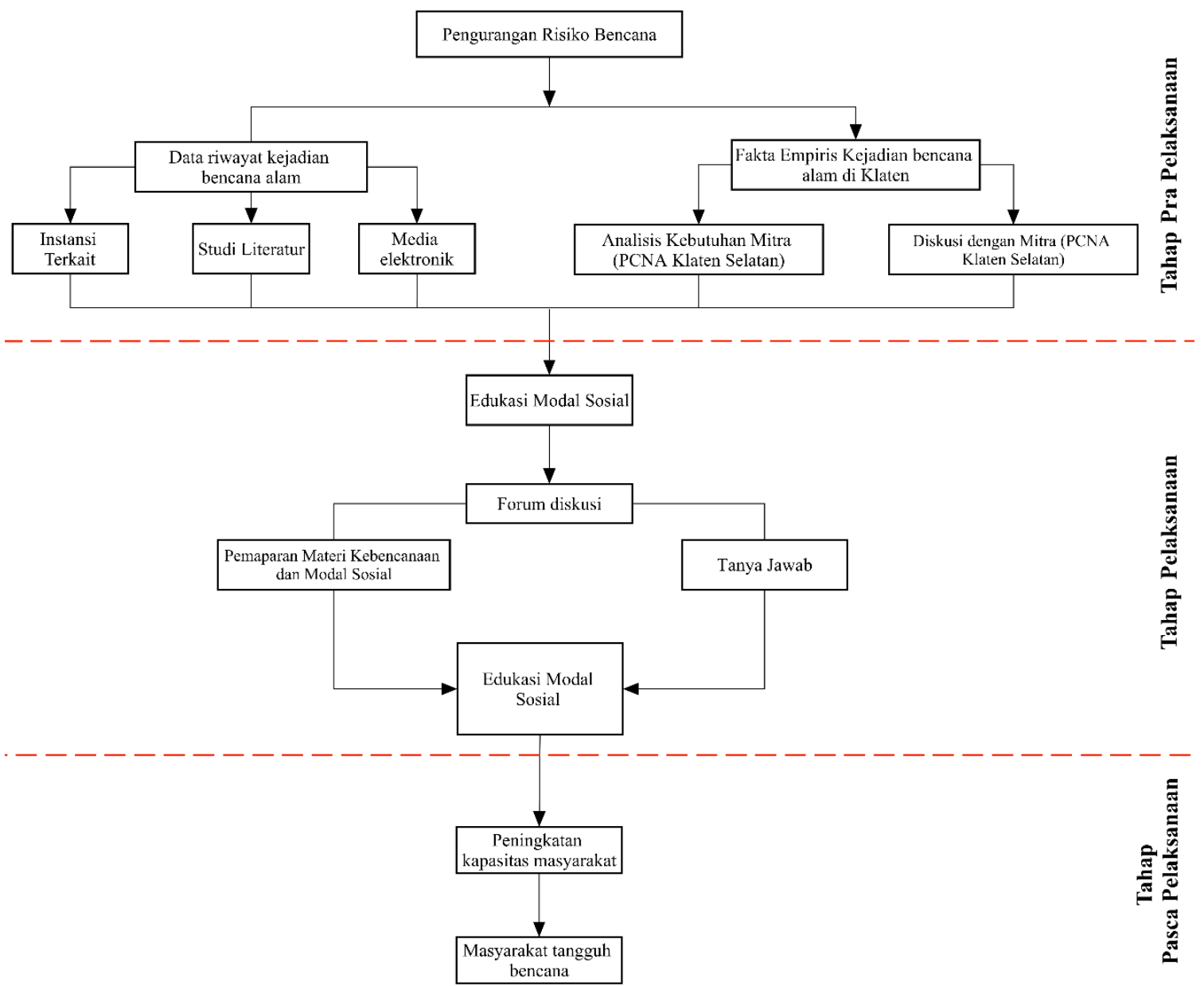

Gambar 4. Skema pelaksanaan sosialisasi dan edukasi modal sosial di Kabupaten Klaten

\section{Hasil dan Pembahasan}

Kabupaten Klaten merupakan salah satu wilayah terdampak gempabumi Tahun 2006. Dampak dari kejadian gempabumi tersebut adalah korban luka, korban jiwa dan kerugian material, sosial-ekonomi. Hal itu dikarenakan Kabupaten Klaten terletak di Pulau Jawa bagian selatan yang berdekatan dengan zona subduksi antara Lempeng Indo-Australia dan Lempeng Eurasia. Konsekuensi logis dari posisi tersebut adalah adanya fenomena tektonik maupun vulkanik.

Fenomena tektonik dan vulkanik mempunyai dampak positif dan negatif. Salah satu dampak positif adalah adanya jalur gunungapi aktif di zona tengah Pulau Jawa, adanya jalur gunungapi tersebut menyebabkan kualitas lahan pada wilayah di sekitarnya termasuk Kabupaten Klaten berkembang menjadi lahan pertanian karena kualitas lahan yang subur. Dampak negatif dari fenomena tektonik dan vulkanik adalah kejadian yang merusak atau mengganggu aktivitas masyarakat, sehingga fenomena tersebut dapat diklasifikasikan sebagai bencana alam. Oleh karena itu diperlukan manajemen bencana yang baik dan terstruktur (Wibowo, Dewi, Ronggowulan, Anjarsari, \& Miftakhunisa, 2020; Wibowo et al., 2019). 
Dalam manajemen kebencanaan, fokus kegiatan dilaksanakan sebelum kejadian, pada saat kejadian dan pasca kejadian. Salah satu variabel yang sangat penting dalam menghadapi bencana alam adalah modal sosial (social capital) (Nakazato \& Lim, 2020; Rustinsyah, Prasetyo, \& Adib, 2020). Modal sosial (social capital) merupakan salah satu variabel yang sangat penting untuk membentuk masyarakat tangguh bencana (Jia, Chowdhury, Prayag, \& Hossan Chowdhury, 2020; Kim, Nakanishi, Blackman, Freyens, \& Benson, 2017; Uekusa, 2020). Meskipun demikian, tingkat pengetahuan masyarakat Kabupaten Klaten tentang modal sosial perlu ditingkatkan.

Upaya peningkatan pengetahuan tentang modal sosial dalam menghadapi bencana gempabumi kepada masyarakat Kabupaten Klaten masih sangat jarang dilakukan baik oleh pemerintah melalui instansi terkait maupun organisasi sosial kemasyarakatan. Nasyiatul Aisyiyah Klaten Selatan merupakan organisasi otonom Muhammadiyah yang bergerak aktif dalam kegiatan sosial kemasyarakatan termasuk dalam bidang kebencanaan. Hal yang menjadi permasalahan adalah belum adanya mitra dalam melaksanakan kegiatan tersebut. Oleh karena itu kegiatan sosialisasi dan edukasi kebencanaan dalam peningkatan pengetahuan masyarakat tentang kebencanaan sangat perlu dilakukan (Wibowo et al., 2020). Kegiatan tersebut diharapkan dapat meningkatkan pengetahuan masyarakat Kabupaten Klaten tentang modal sosial dalam menghadapi bencana gempabumi, sehingga risiko bencana gempabumi di wilayah tersebut dapat dikurangi. Sosialisasi dan edukasi tersebut diharapkan dapat mempererat hubungan antara Nasyiatul Aisyiah Kabupaten Klaten dan Universitas Muhammadiyah Surakarta untuk melaksanakan kegiatan kemasyarakatan khususnya dalam kegiatan manajemen bencana.

Pengabdian masyarakat ini telah dilaksanakan pada hari Minggu Tanggal 11 November 2018 di SMP Muhammadiyah 1 Klaten. Peserta sosialisasi dan edukasi sebanyak 64 peserta yang merupakan pengurus dan kader Nasyiatul Aisyiyah Klaten Selatan, perwakilan dari Muhammadiyah Disaster Management Center (MDMC) Kabupaten Klaten serta perwakilan Komando Kesiapsiagaan Angkatan Muda Muhammadiyah (KOKAM) Kabupaten Klaten. Sebagian besar peserta yang berpartisipasi dalam sosialisasi dan edukasi tersebut merupakan korban gempabumi Tahun 2006 dengan rentang usia 16-35 tahun, sehingga sosialisasi dan edukasi ini tepat sasaran pada korban atau masyarakat terdampak bencana gempabumi.

Sosialisasi dan edukasi ini diawali dengan penyegaran kembali tentang materi kebencanaan khususnya identifikasi bahaya (hazards), kerentanan (vulnerability), risiko (risk) dan mitigasi bencana, selanjutnya materi yang diberikan lebih spesifik mengarah pada modal sosial masyarakat. Materi tersebut secara spesifik membahas tentang bencana, bencana gempabumi, aset penghidupan (livelihood), modal sosial (social capital) dan aspek penting modal sosial dalam manajemen bencana. Masing-masing indikator materi tersebut dirinci lagi menjadi submateri sehingga penjelasan yang diberikan menjadi lebih mendalam dan komprehensif (Tabel 5).

Pelaksanaan edukasi dilaksanakan dengan penyampaian materi secara oral menggunakan media slide show (Microsoft Power Point). Penyampaian materi diawali dengan penyampaian secara runtut dimulai dari materi dasar kebencanaan hingga materi puncak, yaitu aspek penting modal sosial dalam manajemen bencana. Selanjutnya, dilanjutkan sesi tanya jawab dengan peserta edukasi. Sesi tanya jawab berlangsung menarik karena materi modal sosial dalam kebencanaan belum pernah disampaikan kepada peserta baik dari pemerintah maupun pihak-pihak lain. Terdapat tiga penanya yang memberikan pertanyaan terkait dengan modal sosial, di antaranya (1) bagaimana membangkitkan kesadaran akan modal sosial di masyarakat?; (2) bagaimana efektivitas modal sosial dalam membantu masyarakat bangkit akibat dampak bencana di Klaten?; (3) apakah ada fasilitas dari pemerintah terhadap peningkatan pemahaman modal sosial pada masyarakat di kawasan rawan bencana?. Pertanyaan-pertanyaan tersebut merupakan bentuk antusiame peserta yang hadir. Dari pertanyaan-pertanyaan tersebut terciptalah diskusi menarik tentang materi yang disampaikan. 
Tabel 5. Indikator materi dan submateri yang disajikan pada kegiatan edukasi

\begin{tabular}{|c|c|c|}
\hline No. & Materi & Sub Materi \\
\hline \multirow[t]{2}{*}{1.} & Bencana & Definisi \\
\hline & & Klasifikasi \\
\hline \multirow[t]{4}{*}{2.} & Bencana Gempabumi & Definisi \\
\hline & & Penyebab \\
\hline & & Dampak \\
\hline & & Mitigasi \\
\hline \multirow[t]{5}{*}{3.} & Aset Penghidupan (livelihood) & Financial capital \\
\hline & & Physical capital \\
\hline & & Natural capital \\
\hline & & Social capital \\
\hline & & Human capital \\
\hline \multirow[t]{11}{*}{4.} & Modal Sosial (social capital) & Definisi \\
\hline & & $\begin{array}{l}\text { Unsur-unsur: } \\
\text { a. Partisipasi dalam suatu jaringan } \\
\text { (Participation in A Network) }\end{array}$ \\
\hline & & b. Timbal balik sosial (Reciprocity) \\
\hline & & c. Rasa percaya (Trust) \\
\hline & & d. Norma Sosial (Social Norms) \\
\hline & & e. Nilai-nilai (Values) \\
\hline & & f. Tindakan proaktif (Proactive action) \\
\hline & & Jenis-jenis: \\
\hline & & a. Bonding Social Capital \\
\hline & & b. Bridging Social Capital \\
\hline & & c. Linking Social Capital \\
\hline \multirow[t]{4}{*}{5 . } & $\begin{array}{l}\text { Aspek penting modal sosial dalam manajemen } \\
\text { bencana }\end{array}$ & $\begin{array}{l}\text { Masyarakat berisiko (population at risk) } \\
\text { menggunakan sumberdaya }\end{array}$ \\
\hline & & $\begin{array}{l}\text { Pengambilan keputusan oleh masyarakat } \\
\text { melalui jaringan sosial }\end{array}$ \\
\hline & & $\begin{array}{l}\text { Meningkatkan efektivitas dalam tanggap } \\
\text { darurat bencana }\end{array}$ \\
\hline & & $\begin{array}{l}\text { Kondisi modal fisik, manusia dan sosial pada } \\
\text { level yang tinggi memiliki kesiapsiagaan dan } \\
\text { tanggap darurat terhadap bencana yang lebih } \\
\text { baik }\end{array}$ \\
\hline
\end{tabular}

Sumber: (Hasbullah, 2006; Hsueh, 2019; Kawamoto \& Kim, 2019; Kim et al., 2017; Monteil et al., 2020; Putnam, 1993)

Hasil sosialisasi dan edukasi tentang modal sosial mendapatkan respon dan manfaat yang baik bagi masyarakat melalui PCNA Klaten Selatan. Berdasarkan hasil diskusi dan pendapat yang disampaikan oleh setiap peserta terhadap kegiatan edukasi maka dapat disimpulkan bhawa edukasi tersebut memberikan manfaat yang baik dalam upaya peningkatan kapasitas masyarakat di kawasan rawan bencana. Manfaat tersebut dikelompokkan ke dalam tiga hal utama, di antaranya:

a. Meningkatkan pengetahuan dan persepsi masyarakat terhadap definisi, arti penting dan manfaat dari modal sosial dalam membangun masyarakat tangguh bencana.

b. Meningkatkan kapasitas masyarakat dalam menghadapi bencana alam, sosialisasi dan edukasi ini memberikan pengetahuan tambahan tentang modal sosial yang sangat penting bagi masyarakat karena belum pernah disampaikan atau dilakukan sebelumnya.

c. Sosialisasi ini dijadikan sebagai langkah awal dalam meningkatkan kesadaran masyarakat akan pentingnya modal sosial yang terdiri atas interaksi antar individu dalam masyarakat seperti pertemuan rutin rukun tetangga, pertemuan rutin PKK, pertemuan rutin pengajian, Pos Pelayanan Terpadu, kerja bakti/ gotong royong lingkungan, Pos Keamanan Lingkungan, karang taruna, dan berbagai kegiatan kemasyarakatan lainnya yang dapat meningkatkan ikatan antar anggota masyarakat. 

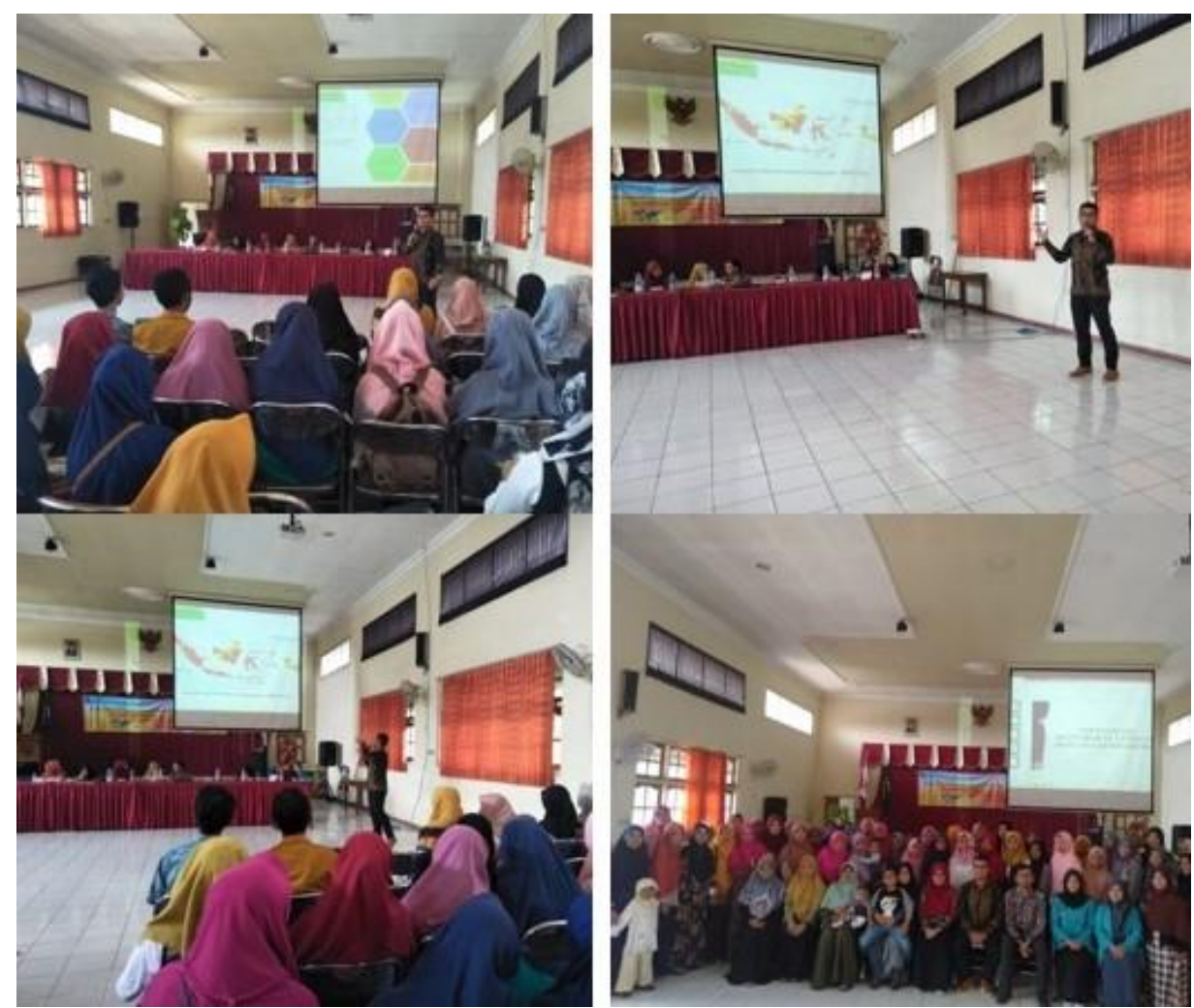

Gambar 5. Tahap pelaksanaan sosialisasi dan edukasi dengan tema membangun masyarakat tangguh bencana melalui modal sosial di Kabupaten Klaten

Selain manfaat tersebut, keberlanjutan dari sosialisasi dan edukasi ini adalah terjalinnya hubungan antara Perguruan Tinggi Muhammadiyah dengan Organisasi Otonom khususnya PCNA Klaten Selatan untuk berperan aktif dalam membangun masyarakat tangguh bencana di Kabupaten Klaten. Hal itu direncanakan dilakukan melalui komunikasi baik langsung maupun secara tidak langsung untuk melaksanakan program-program yang berkaitan dengan membangun masyarakat tangguh bencana dengan lingkup yang lebih luas dan disertai dengan simulasi bencana. Pelaksanaan sosialisasi dan edukasi dengan tema membangun masyarakat tangguh bencana melalui modal sosial di Kabupaten Klaten disajikan pada Gambar 5.

\section{Simpulan}

Sosialisasi dan edukasi dengan tema "Membangun Masyarakat Tangguh Bencana Melalui Modal Sosial di Kabupaten Klaten" secara keseluruhan berjalan dengan lancar. Materi yang disampaikan tepat sasaran yaitu masyarakat terdampak gempabumi di Kabupaten Klaten. Berdasarkan hasil pelaksanaan, peserta sosialisasi dan edukasi sangat antusias dengan materi yang diberikan karena pada kegiatan-kegiatan yang hampir serupa belum pernah dipaparkan materi tentang modal sosial yang sebenarnya hal itu sangat erat dan melekat dalam kehidupan seharihari masyarakat. Sosialisasi dan edukasi tersebut dapat dilanjutkan dengan materi-materi lainnya yang dibutuhkan masyarakat dan diadakan dengan kegiatan simulasi bencana agar kapasitas masyarakat yang telah terbangun dapat lebih komprehensif dengan terintegrasinya teori-teori kebencanaan dengan praktek lapangan dalam bentuk simulasi bencana.

Keterbatasan dalam kegiatan ini adalah jumlah peserta dan belum sampai tahap simulasi bencana. Diharapkan kegiatan peningkatan kapasitas masyarakat di Kawasan rawan bencana dapat lebih diintesifkan tidak hanya oleh pemerintah tetapi juga organisasi kemasyarakatan serta organisasi pendidikan. Jika sinergi tersebut dapat tercipta, maka tujuan menuju masyarakat tangguh bencana akan tercapai. 


\section{Persantunan}

Ucapan terima kasih dan apresiasi diberikan kepada Program Studi Pendidikan Geografi, Fakultas Keguruan dan Ilmu Pendidikan, Universitas Muhammadiyah Surakarta, PCNA Klaten Selatan dan KOKAM Klaten Selatan yang mendukung terlaksananya kegiatan ini.

\section{Referensi}

Abbott, P. L. (2017). Natural Disasters (10th ed.). Boston: McGraw Hill Higher Education.

Bird, P. (2003). An updated digital model of plate boundaries. Geochemistry, Geophysics, Geosystems, 4(3). https://doi.org/10.1029/2001GC000252

BMKG. (2018). Gempabumi. https://doi.org/http://www.bmkg.go.id.

DFID. (1999). Sustainable Livelihoods Guidance Sheets Introduction: Overview. In Sustainable Livelihoods Guidance Sheets. London: DFID. Retrieved from https://www.livelihoodscentre.org/documents/114097690/114438878/Sustainable+liveliho ods+guidance+sheets.pdf/594e5ea6-99a9-2a4e-f288-cbb4ae4bea8b?t=1569512091877

Ellis, F. (1999). Rural Livelihood Diversity in Developing Countries: Evidence and Policy Implications. ODI Natural Resources Perspectives, 40. Retrieved from https://www.odi.org/sites/odi.org.uk/files/odi-assets/publications-opinion-files/2881.pdf

Elnashai, A. S., Kim, S. J., Yun, G. J., \& Sidarta, D. (2006). The Yogyakarta Earthquake of May 27. Illinois: Headquarters: University of Illinois at Urbana-Champaign.

Hasbullah, J. (2006). Social capital (menuju keunggulan budaya manusia Indonesia. Jakarta: MRUnited Press.

Hsueh, H. Y. (2019). The role of household social capital in post-disaster recovery: An empirical study in Japan. International Journal of Disaster Risk Reduction, 39, 101199. https://doi.org/10.1016/j.ijdrr.2019.101199

Husein, S. (2016). Bencana Gempabumi. DRR Action Plan Workshop: Strengthened Indonesian Resilience: Reducing Risk from 1-10. https://doi.org/10.13140/RG.2.1.1112.6808

Jia, X., Chowdhury, M., Prayag, G., \& Hossan Chowdhury, M. M. (2020). The role of social capital on proactive and reactive resilience of organizations post-disaster. International Journal of Disaster Risk Reduction, 48, 101614. https://doi.org/10.1016/j.ijdrr.2020.101614

Karunarathne, A. Y., \& Lee, G. (2019). Traditional social capital and socioeconomic networks in response to flood disaster: A case study of rural areas in Sri Lanka. International Journal of Disaster Risk Reduction, 41, 101279. https://doi.org/10.1016/j.ijdrr.2019.101279

Kawamoto, K., \& Kim, K. (2019). Efficiencies of bonding, bridging and linking social capital: Cleaning up after disasters in Japan. International Journal of Disaster Risk Reduction, 33, 64-73. https://doi.org/10.1016/j.ijdrr.2018.09.010

Kim, C., Nakanishi, H., Blackman, D., Freyens, B., \& Benson, A. M. (2017). The Effect of Social Capital on Community Co-production: Towards Community-oriented Development in Postdisaster Recovery. Procedia Engineering, 180, 901-911. https://doi.org/10.1016/j.proeng.2017.04.251

Marfai, M.A., Cahyadi, A., Fatchurohman, H., Rosaji, F. S. C., \& Wibowo, Y. A. (2019). Tsunami preparedness and environmental vulnerability analysis in Kukup Beach, Gunungkidul, Indonesia. IOP Conference Series: Earth and Environmental Science, 256(1). https://doi.org/10.1088/1755-1315/256/1/012025

Marfai, Muh Aris, Cahyadi, A., Fatchurohman, H., Rosaji, F., \& Wibowo, Y. A. (2017). Analisis Kesiapsiagaan dan Kerentanan Lingkungan Terhadap Bencana Tsunami di Pantai Kukup, 
Kabupaten Gunungkidul. Seminar Nasional III Pengelolaan Pesisir Dan Daerah Aliran Sungai. https://doi.org/10.31227/osf.io/fkh2b

Monteil, C., Simmons, P., \& Hicks, A. (2020). Post-disaster recovery and sociocultural change: Rethinking social capital development for the new social fabric. International Journal of Disaster Risk Reduction, 42, 101356. https://doi.org/10.1016/j.ijdrr.2019.101356

Nakazato, H., \& Lim, S. (2020). Interplay between social support tie formations and subjective mental health conditions in a community currency system in Japanese disaster-affected communities: The ambivalent effects of social capital. International Journal of Disaster Risk Reduction, 51(May), 101809. https://doi.org/10.1016/j.ijdrr.2020.101809

Posko Kemanusiaan Dengkeng Wedi Klaten. (2006). Kondisi Desa Dengkeng, Wedi, Klaten Pasca Gempa. Retrieved from http://poskodengkeng.blogspot.com/2006/06/kondisi-desadengkeng-wedi-klaten.html

Putnam, R. D. (1993). The Prosperous Community: Social Capital and Public Life. The American Prospect, (13), 35-42. Retrieved from http://prospect.org/

Rustinsyah, R., Prasetyo, R. A., \& Adib, M. (2020). Social capital for flood disaster management: Case study of flooding in a village of Bengawan Solo Riverbank, Tuban, East Java Province. International Journal of Disaster Risk Reduction, 101963. https://doi.org/10.1016/j.ijdrr.2020.101963

Story, W. T., Tura, H., Rubin, J., Engidawork, B., Ahmed, A., Jundi, F., ... Abrha, T. H. (2020). Social capital and disaster preparedness in Oromia, Ethiopia: An evaluation of the "Women Empowered" approach. Social Science and Medicine, 257. https://doi.org/10.1016/j.socscimed.2018.08.027

Uekusa, S. (2020). The paradox of social capital: A case of immigrants, refugees and linguistic minorities in the Canterbury and Tohoku disasters. International Journal of Disaster Risk Reduction, 48, 101625. https://doi.org/10.1016/j.jjdrr.2020.101625

Wibowo, Y. A., Dewi, R. P., Ronggowulan, L., Anjarsari, R. Y., \& Miftakhunisa, Y. (2020). Penguatan Literasi Mitigasi Bencana Angin Puting Beliung untuk Peningkatan Kapasitas Masyarakat Desa Munggur, Kabupaten Boyolali, Jawa Tengah. Warta LPM, 23(2), 165179. https://doi.org/10.23917/warta.v23i2.10571

Wibowo, Y. A., Ronggowulan, L., Arif, D. A., Afrizal, R., Anwar, Y., \& Fathonah, A. (2019). Perencanaan Mitigasi Bencana Banjir Non-Struktural Di Daerah Aliran Sungai Comal Hilir, Jawa Tengah. JPIG (Jurnal Pendidikan Dan Ilmu Geografi), 4(2), 87-100. https://doi.org/10.21067/jpig.v4i2.3632

\section{c) $(9 \Theta$}

(C) 2021 by the authors. Submitted for possible open access publication under the terms and conditions of the Creative Commons Attribution (CC-BY-NC-ND) license (http://creativecommons.org/licenses/by/4.0/). 